\title{
Effect of Different Irrigation Intervals and Foliar Spray with Some Anti-Transpiration on Growth and Productivity of Some Tomato Grown Under Saline Soil Conditions Bard, L. A., M.H.M, Mohamed, H.M. Elkoumy* and H.S.S. El- Shafay* \\ Horticulture Dept., Fac. Of Agric., Benha university and * Hort.Res. Institute, Agriculture Research Center,
} Egypt.

\begin{abstract}
Two field experiments were carried out during the two successive summer seasons of 2017 and 2018 in a private sector farm at Kafr El-Sheikh Governorate, to investigate the effect of four irrigation intervals (every 10days, 15ays, 20ays and 25days) and foliar spray with Kaolin $6 \%$ at $60 \mathrm{~g} / \mathrm{l}$ and Glycine betaine at $2 \mathrm{~g} / \mathrm{l}$ on vegetative growth, chemical composition, fruit yield and quality of tomato cv. Super strain B under saline soil conditions. This study included 12 treatments which were resulted from thecombinations between four irrigation treatments (Irrigation every 10 days, 15 days, 20 days and 25 days and three foliar spray with Kaolin $6 \%$ at $60 \mathrm{~g} / \mathrm{l}$ and Glycine betaine at $2 \mathrm{~g} / \mathrm{lin}$ addition to control treatments (without spray). Results clearly showed that the highest values in all measured growth traits were recorded as a result of using irrigation every 10 days (2850 $\mathrm{m} 3 / \mathrm{fed}$ ) and spraying with kaolin at $60 \mathrm{~g} / \mathrm{l}$. moreover, the highest values of the most fruit yield and its components (total yield $\mathrm{kg} / \mathrm{plant}$, total yield $\mathrm{t} / \mathrm{fed}$ and marketable yield $\mathrm{t} / \mathrm{fed}$ ) were recorded as a result of using irrigation every 10 days ( $2850 \mathrm{~m} 3 /$ fed) followed by irrigation every 15 and 20 days( 2550 and $2150 \mathrm{~m} 3 /$ fed, respectively) with foliar spray with kaolin $6 \%$ at $60 \mathrm{~g} / \mathrm{L}$ and gave the highest average fruit weight, length, diameter, fruit firmness, T.S.S., vitamin $\mathrm{C}$ and total acidity of produced fruit.
\end{abstract}

Keywords: Tomato - salinity - irrigation intervals -anti-transpiration- Kaolin - Glycine betaine - fruit yield- fruit

\section{Introduction} quality

Tomato (Solanum lycopersicum Mill) is the most popular and widely grown Solanaceae vegetable crop in Egypt. In each corner of the world, the major producers of tomatoes were the united states, Turkey, Egypt, India and Italy. Egypt produces 6723250 ton yearly the average devoted for tomato planting 395571 fed with an average 16.90 ton/fed. according to the statistics of Ministry of Agriculture 2017. Tomatoes are popular for their culinary properties and their health benefits. Tomatoes and tomato plantingbased products account for more than $85 \%$ of the dietary lycopene. Consumers demand tomatoes for many of their original characteristics. This means maintaining the color, nutritional content and level of antioxidant compounds present in the fresh fruits. These fruits include vitamins A, C, E and carotenoids such as beta- carotene and lycopene. Tomato production is limited by many environmental such as soil salinity, soil fertility, water quality, irrigation method and meteorological factors like temperature, relative humidity and wind speed. Productivity and quality depend upon the chosen cultivar and other factors which are related to soil characteristics and farming practices.

The application of deficit irrigation and kaolin suspension might be some of the options for mitigation negative effects of drought caused by climate change and for saving water in agricultural production. The application of deficit irrigation aims to save irrigation water, increase water use efficiency and achieve optimal yields (Topuc etal., 2007). By applying the strategy of deficit irrigation, crops are systematically exposed to moderate levels of stress due to a lack of water for a certain period or during the entire vegetation, which results in lowering yields, but also to cost saving and increasing efficiency of water use (Pereira etal ., 2002). Basically, the method of deficit is to reduce amount of applied irrigation water to such extent to cause the adaptive response of plants to drought, enabling them to increase the efficiency of water use and maintain yields, while increasing the quality of fruits (Savic, 2008). Before a decision is made on the application of deficit irrigation regimes, it is important toassess its impact on different cultures on the basis of many years of experimental research(Lgbadum etal ., 2008). Application of kaolin leads to shadowing of the plant )aboveground part and fruits which leads to reduction in water consumption. Kaolin - based particle film technology (PFT) has been developed over the past 15 years as amulet- functional , environment friendly material, that provides effective insect control mitigates heat stress, and contributes to the production of high - quality fruit and vegetables , as well as being suitable for organic farming (Glenn and Puterka, 2005). Boar et al. (2015) have followed the effect of kaolin on a variety of crops (tomatoes, peppers). Their results indicate that the kaolin had the biggest impact on reducing stomatal conductance, which contributed to reduction in transpiration and improved the water regime of plants, reducing the net assimilation. Kaolin is non-toxic aluminum silicate $\left(\mathrm{AL}_{4} \mathrm{SL}_{4} \mathrm{O}_{10}\left(\mathrm{OH}_{8}\right)\right.$ clay mineral kaolin spray was found to decrease leaftemperature by increasing leaf reflectance and to reduce transpiration rate more than photosynthesis in plants grown at high solar radiationlevels ( Nakano and Uehara 1996 ). Studies conducted on tomato and potato have shown that foliar applications ofkaolin particle films reduce plant stress, which is important for optimum plant growth, yield and quality (Cantore etal., 2009). 
Glycine betaine (GB) is an amino acid derivative which accumulates in a variety of plant species in response to environmental stresses such as drought, salinity and extreme temperatures.However, there many important crop species, like potato or tomato are unable to accumulate GB 31 thus, as an alternative, exogenous applications of GB may be a possible approach to tolerate environmental stress. In Egypt, water was and still the most critical and limited factor in crop production. The Egyptian water budget from the Nile River is 55.5 milliard cubic meter. Under limitation of fresh water resources the farmers will have to use other resources in irrigation, and we should do our best towards effective rationalization of irrigation on the farm level. So, effective water management at irrigation sector is the principal way towards the rationalization policy for the country in this aspect, effective on farm irrigation management becomes amust.Therefore, the knowledge of amount of water required to produce the highest economical yield is essential.

IN Egypt, it is necessary to produce the maximum yield and profit from unit area by using available water efficiently because the existing agricultural land and irrigationwater arerapidly diminishing. Consequently, it is important tofind ways by which available watercould beeconomically utilized. One way, to achieve thisgoal, is to reduce thetranspiration rate. Using antitranspirants such as kaolin may reduce transpiration rate from the plant; Consequently reduce the amount of used water and improved the water use efficiency while it did not reduce carbon assimilation (Cantore etal; 2009 ) The goal of deficit irrigation is to increase crop water use efficiency (WUE) by reducing the number of irrigation events ( Kirda, 2002 ). The DI process irrigates the root zone withless water than that required forevapotranspiration and makes use of suitable irrigation schedules, which are usually derived from field trails (Oweis and Hachum, 2001).

Therefore, the main target for this present study was to investigate the effect of foliar application of by some antitranspirants on water saving by plant tissues through long drought periods and its effect on productivity, quality of tomato under saline soil conditions.

\section{Materials and Methods}

Two field experiments were carried out during the two successive summer seasons of 2017 and 2018 in a private sector farm at Kafr El-Sheikh Governorate, to investigate the effect of different irrigation intervals and some anti-transparent treatments on plant growth, fruit yield and its components as well as chemical composition for both plant foliage and fruits of tomato plants c.v. Super strain B under Kafr El-Sheikh Governorate conditions.

The soil of the experimental field was clay in texture with $\mathrm{pH}$ 7.39. Soil samples were taken at 30 $\mathrm{cm}$ from soil surface and soil physical and chemical properties were determined according to Jackson (1973) and Black et al. (1982) and were illustrated at Table (a). Moreover, maximum and minimum air temperature (c0) and relative humidity \% Kafr ElSheikh region during two seasons of study. are shown in Table (b).

Table a. Average mechanical and chemical analyses of theexperimental soil during the two seasons of growth.

\begin{tabular}{|c|c|c|c|c|c|}
\hline \multirow{2}{*}{\multicolumn{2}{|c|}{ Physical analysis }} & \multicolumn{4}{|c|}{ Chemical analysis } \\
\hline & & \multicolumn{2}{|c|}{ Cations meq/l } & \multicolumn{2}{|c|}{ Anions meq/l } \\
\hline Coarse sand & $18.3 \%$ & $\mathrm{Ca}^{++}$ & 5.40 & $\mathrm{CO}^{--}$ & $\begin{array}{c}--- \\
-9\end{array}$ \\
\hline Fine sand & $12.8 \%$ & $\mathrm{Mg}^{++}$ & 4.54 & $\mathrm{HCO}^{-}$ & 2.00 \\
\hline Silt & $13.5 \%$ & $\mathrm{Na}^{+}$ & 15.55 & $\mathrm{Cl}^{-}$ & 14.79 \\
\hline Clay & $55.4 \%$ & $\mathrm{~K}^{+}$ & 0.11 & $\mathrm{SO}^{--}$ & 8.81 \\
\hline Texture class & \multicolumn{5}{|l|}{ clay } \\
\hline Soil pH (1: 2.5 soil water suspension) & 7.39 & \multicolumn{2}{|c|}{ Available $\mathrm{N}$} & \multicolumn{2}{|l|}{$23.9 \mathrm{mg} / \mathrm{kg}$} \\
\hline E.C, $\mathrm{dS} / \mathrm{m}$ & 2.56 & \multicolumn{2}{|c|}{ Available P } & \multicolumn{2}{|l|}{$12.6 \mathrm{mg} / \mathrm{kg}$} \\
\hline Organic matter & $2.6 \%$ & \multicolumn{2}{|c|}{ Available $\mathrm{K}$} & \multicolumn{2}{|l|}{$183 \mathrm{mg} / \mathrm{kg}$} \\
\hline
\end{tabular}

Table b. Monthly air temperature and relative humidity in Kafr El-Sheikh region during two seasons of study.

\begin{tabular}{ccccccc}
\hline & \multicolumn{3}{c}{$\mathbf{2 0 1 7}$} & \multicolumn{3}{c}{$\mathbf{2 0 1 8}$} \\
\cline { 2 - 7 } Mmperature ${ }^{\circ} \mathbf{C}$ & R.H\% & Tmperature & ${ }^{\circ} \mathbf{C}$ & R.H\% \\
\hline Months & Max & Min & Average & Max & Min & Average \\
\hline March & 18.3 & 6.5 & 70 & 19.3 & 7.2 & 69 \\
\hline April & 27.1 & 10.1 & 65 & 25.3 & 10.3 & 64 \\
\hline May & 30.9 & 15.6 & 64 & 30.4 & 16.6 & 63 \\
\hline June & 34.1 & 18.3 & 61 & 32.7 & 19.7 & 60 \\
\hline July & 37.6 & 19.6 & 65 & 37.6 & 22.5 & 67 \\
\hline
\end{tabular}

The area of the experimental sub plot was $10.5 \mathrm{~m}^{2}$.Each experimental plot included four ridges
3.5 meters in long and 1 meter in width. From which, three ridges were planted and one was left as a guard 
between plots to prevent water movement from any plot to adjacent one. Transplanting was done on one side of ridge at $50 \mathrm{~cm}$ apart between seedlings. Transplanting was done on $7^{\text {th }}$ and $9^{\text {th }}$ of March in 2017 and 2018, respectively. All agriculture practices were done as recommended by Ministry of Agriculture and land reclamation for the crop and the studied area.

The experiment included 12 treatments which were the combinations of four irrigation treatments and three tomato hybrids as follow:

\section{A-Irrigation intervals.}

The irrigation intervals used in this experimental were as follows:

1- Irrigation every 10 days (10 - days).

2- Irrigation every 15 days (15 - days).

3 - Irrigation every 20 days ( 20 - days).

4- Irrigation every 25 days ( 25 - days).

The irrigation treatments began after transplanting irrigation.

A- Antitranspirants treatments.

The antitranspirants treatments used in these experiments were as follow:

1- Kaolin $6 \%$ at $60 \mathrm{~g} / \mathrm{L}$.

2- Glycine betaine at $2 \mathrm{~g} / \mathrm{L}$.

3- The control treatment (without spray).

In both seasons, split plot design with four replications was used in this experiment where the main plots were devoted to four irrigation intervals and sub plots were occupied by foliar spay with antitranspirants.

Antitranspirant (kaolin, glycine betaine) were sprayed at 25, 40 and 55 days after planting. Plants were sprayed with a hand pressure sprayer till run- off, with care being taken to cover all plant parts; no surfactants or other wetting agents were needed. The control plants were sprayed with distilled water.

Kaolin is non-toxic aluminum silicate ( $\mathrm{Al} 4 \mathrm{~S} 14 \mathrm{O} 10$ (OH8) ) clay mineral .

Glycine betaine (GB) is an amino acid derivative witch accumulates in a variety of plant species in response to environmental stresses such as drought, salinity and extreme temperatures. However, there are many important crop species, like potato or tomato are unable to accumulate GB. Thus, as an alternative, exogenous application of GB may be a possible approach to tolerate environmental stress.

The agricultural practices concerning cultivation, fertilization, irrigation, insect and disease control were conducted as commonly followed according to the recommendation of the ministry of Agriculture for the commercial production of tomato.

\section{Data recorded:}

\section{a. Vegetative growth characteristics.}

Three plants were taken from each experimental plot as a representative sample after 70 days from transplanting and the following data were recorded. plant height, number of branches and leaves/plant, fresh and dry weight per plant and Leaf area/plant.

\section{b. Chemical composition of plant foliage:}

Total chlorophyll, carbohydrates, nitrogen, phosphorus, potassium, and proline content were determined according to Murquard and Timpton (1987), Cherry (1973), Pregl (1945), John (1970), Brown and Lilleland (1964) and Bates, et al., (1973), respectively.

At harvest mature fruits were picked along the harvesting season and the following data were recorded

Total fruit yield/fed: It was calculated using plot yield and plot area.

Fruit yield/plant: It was calculated form fruit yield/plot and number of plants/plots.

Marketable fruit yield/fed: it was calculated as weight of harvested fruits after discarding the misshaped fruits.

Unmarketable yield /fed: it was calculated as weight of infected and the misshaped fruits.

Early yield

Water use efficiency

Water use efficiency expressed as water economy, was calculated using the following equation of Begg and Turner (1976).

Water economy $\left(\mathrm{kg} / \mathrm{m}^{3}\right)=$

Total yield (kg/fed.)

\section{Total amount of applied water $\left(\mathrm{m}^{3} / \mathrm{fed}.\right)$}

\section{d. Fruit quality}

1- Physical quality: A random sample of 10 fruits at full ripe stage from each experimental plot was taken to determine the following properties. Average fruit weight, length, diameter and firmness. Fruit firmness $\left(\mathrm{g} / \mathrm{cm}^{2}\right)$ was determined by using digitalis Penetrometer (PCE-PTR.MITPC, USA) with a needle $8 \mathrm{~mm}$ in diameter.

\section{Chemical quality:}

Total soluble solids (T.S.S.): A random sample of 10 fruits from each experimental plot at full ripe stage was taken to determine the percentage of soluble solid content by using the hand refractometers.

Total titratable acidity (T.T. A) and L. ascorbic acid were determined according to the method described in A. O. A.C. (1990).

\section{Statistical analysis:}

The analysis of variance was carried out according to Gomez and Gomez (1984). Treatment means were compared by Duncan's Multiple Rang Test (Duncan, 1955). Statistical analysis of variance was done using COSTAT software package.

\section{RESULTS}

1. Vegetative growth characteristics. 
Concerning the effect of irrigation intervals data in table (5) showed that irrigation every 10 days( irrigation at soil moisture content $\%$ of field capacity) followed by irrigation every 15 days (irrigation at soil moisture content $\%$ of field capacity) during the growing season recorded the highest values of vegetative growth and increased all measured vegetative growth parameters expressed as plant height, number of branches and leaves per plant and fresh weight of plant without significant differences between them compared with other irrigation treatments under study in both seasons, while irrigation every 10 days, 15 days and 20 days (irrigation at soil moisture content \% of field capacity, respectively) recorded the highest values of dry weight of plant and leaves area with no significant differences among them compared with other irrigation treatments under study in both seasons. On the other hand, the irrigation every 25 days (irrigation at soil moisture content $\%$ of field capacity) recorded the lowest values of all measured vegetative growth traits in both seasons of study. This resultis true in both seasons of study. The increments in plant growth traits due to increasing irrigation level may be attributed to the role of water in accelerating the physiological processes and increasing the solubility and up take of macro- nutrients which constitute and incorporated in the formation of protoplasmic materials necessary for cell formation and consequently increasing the plant growth. Similar results were obtained by numerous of investigator, i.e.,Abdala alli et al.(2012), Pet Roey et al. (2015) Abd El-hady et al.(2017) and Malash et al.(2019b).

With regard to the effect of foliar spray treatments with some antitranspiration substances, the same data in Table (5) indicate that spraying leaves of the plants with kaolin at concentration of $6 \%(60 \mathrm{~g} / \mathrm{L})$ and glycine betaine $(2 \mathrm{~g} / \mathrm{L})$, three times during the growing season starting after three weeks from transplanting and every two weeks by intervals, significantly increased all studied morphological parameters compared with the control treatment during the two seasons of growth .In this concept , spraying the plants with kaolin exhibited the highest values in all measured growth traits followed by using glycine betainewhich recorded the highest values with significant differences between them fornumber of branches and leaves/plant, fresh weight, dry weight and leaves area except plant height which did not reach the level of significance in both seasons of study compared with the control treatment which gave the lowest values of all measured growth characteristics in both seasons.In this concern, Francesca Boari et al. (2016), Nevenka et al. (2016) , Marija et al. (2018), Ahmed AbdAllah (2019). Da Silvaa et al.(2019), Malash et al. (2019)reported that are variation among tomato plants for all vegetative growth characteristics.

As for the effect of the interaction treatments between irrigation intervals and foliar spray withsome anti- transpiration substances, the same data in table (5) revealed that the highest values in all measured growth traits were recorded as a result of using irrigation every 10 days $\left(2850 \mathrm{~m}^{3} / \mathrm{fed}\right)$ followed by irrigation every 15 days $\left(2550 \mathrm{~m}^{3} / \mathrm{fed}\right.$ ) and spraying with kaolin and glycine betainewith no significant between them for plant height, number of branches and leaves /plant and fresh weight in both seasons of study. While, irrigation the plants every 10 days , 15 days and 20days and spraying with kaolin $(60 \mathrm{~g} / \mathrm{L})$ and glycine betaine $(2 \mathrm{~g} / \mathrm{L})$ recorded the highest values of dry weight and leaves areawith no significant differences among them in both seasons. On the other hand, irrigation every 25 days $\left(2100 \mathrm{~m}^{3} / \mathrm{fed}\right)$ recorded the lowest values for all measured vegetative growth characteristics and spraying with all antitranspiration substances especially control treatments in both seasons of study.

\section{Chemical composition of plant foliage:-}

Data given in table (6) indicated clearly that irrigated tomato plants every 10days ( irrigation at soil moisture content $\%$ of field capacity) followed by 15 days ( irrigation at soil moisture content $\%$ of field capacity)during the two seasons of growth gives the maximum values and increased all assayed chemical constituents of plant foliage i.e, total chlorophyll reading and macro elements ( $, \mathrm{P}, \mathrm{K}$ percentage ) without significant differences between them compared with other irrigation treatments under study in both seasons except proline and carbohydrates content. On the other hand, irrigation every 25 days (irrigation at soil moisture content $\%$ of field capacity) gives higher proline and carbohydrates content compared with other irrigation treatments under study and recorded the lowest values of total chlorophyll reading and macro elements $(\mathrm{N}, \mathrm{P}, \mathrm{K}$ percentage ) in both seasons of study. In this respect, the reduction in proline and carbohydrates concentration in plant foliage as a result of increasing the irrigation rate may be due to the distribution of the amounts of proline and carbohydrates on large vegetative weight of plant as indicated in table (5) and consequently decreased the concentration of it in thispart of plant. Obtained results are in agreement with those reported by Abdala ali $\boldsymbol{e t}$ al.(2012), Zhu et al. (2012), Abd El-hady et al.(2017), El-Zawily et al. (2019), Jianshe et al. (2019) and Malash et al. (2019).

With regarding the effect of foliar spry with someantitranspiration substances the same data in Table (6) revealed that the highest values of all measured chemical constituents (total chlorophyll reading, $\mathrm{N}, \mathrm{P}$ and $\mathrm{K}$ ), proline and carbohydrate were recorded by using kaolin spray $(60 \mathrm{~g} / \mathrm{L})$ followed by glycine betaine $(2 \mathrm{~g} / \mathrm{L})$ in both seasons of study. Moreover, kaolin and glycine betaine recorder the higher proline content in second season and carbohydrates content in both seasons of studywithout any significant differences between them compared with the control treatment which gave the lowest 
values of all measured chemical constituents. Similar results were reported by Ragab et al.(2015), Da Silvaa et al.(2019) and Malash et al. (2019).

As for the effect of the interaction treatments between irrigation intervals and foliar spray with some anti-transpiration substances, the same data in table (6) indicated that spraying tomato plants three times during the growing seasons starting after three weeks from transplanting and every two weeks by intervals using kaolin $6 \mathrm{~g} / \mathrm{L}$ and glycine betaine $2 \mathrm{~g} / \mathrm{Lunder}$ irrigation every $10\left(2850 \mathrm{~m}^{3} / \mathrm{fed}\right)$ and 15 days $(2550$ $\mathrm{m}^{3} / \mathrm{fed}$, respectively) recorded the highest values of the most chemical constituents ( chlorophyll reading , $\mathrm{N}$ and $\mathrm{K}$ ) in both seasons of study without any significant differences between them compared with other interaction treatments. However, plants irrigated every 25 days $\left(2100 \mathrm{~m}^{3} / \mathrm{fed}\right)$ and foliar spray kaolin followed by glycine betaine recorded the highest values of proline content and carbohydrates content without any significant differences between them and recorded the lowest values of other chemical constituents (chlorophyll reading, $\mathrm{N}$ and $\mathrm{K}$ ) in 2017 and 2018 seasons. Moreover, phosphorus concentration did not reach the level of significance under all irrigation treatments and foliar spray with some anti-transpiration substances. Obtained results are true during both seasons of growth.

\section{Fruit yield and its components as well as water use efficiency.}

Data presented in table (7) showed that total produced fruit yield and its components expressed as early and total fruit yield per plant, marketable and unmarketable fruit yield as well as total fruit yield per fedden were significantly affected as a result of irrigation intervals treatments. In this respect, the plants irrigated every 10 days, 15 days and 20 days( irrigation at soil moisture content $\%$ of field capacity, respectively) during the growing seasons significantly increased and produced fruit yield per plant as well as marketable and total fruit yield/fed without any significant differences between them, On the other hand it decreased the unmarketable fruit yield compared with other irrigation treatments under study. In this regard, using irrigation every 10 exhibited the highest values of early yield per plant compared with other tested irrigation treatments in both seasons of study. In this respect, irrigation every 20 days recorded the highest values of water use efficiency in both seasons compared with other treatments under study. On the other hand, irrigation every 25 days( irrigation at soil moisture content $\%$ of field capacity) recorded the lowest values of fruit yield and its components except unmarketable yield, which increased by using irrigation every 25 days in both seasons compared with other irrigation treatments in this study. The increases in total fruit yield and its components are very tightly related with increasing in average fruit weight, fruit length and fruit diameter (8). Also, such increaments in total fruit yield and its components due to increasing the amounts of irrigation water applied are connected with the enhancing effect of irrigation water on vegetative growth of plant (table5) which in turn affect on the yielding ability of plant.These finding are in agreement with those obtained by previously Hui $\boldsymbol{e t}$ al. (2018), Ahmed AbdAllah (2019), El-Zawily et al.(2019), Hao Liu et al. (2019),Jia Lu et al. (2019) ,Khapteet al. (2019)and Malash et al. (2019).

With regard to the effect of foliar spray with some antitranspiration substances, the same data in Table (7) indicate that spraying the plants with kaolin at concentration of $6 \%(60 \mathrm{~g} / \mathrm{L})$ and glycine betaine $(2 \mathrm{~g} / \mathrm{L})$, three times during the growing season starting after three weeks from transplanting and every two weeks by intervals significantly increased all studied fruit yield and its components traits except unmarketable fruit yield as well as water use efficiency compared with the control treatment during the two seasons of growth.In this concept, spraying the plants with kaolin exhibited the highest values of the most fruit yield and its components as well as water use efficiency followed by using glycine betaine which recorded the highest values of total fruit yield $\mathrm{kg} /$ plant and feddan, marketable fruit yield (t/fed) and early yield per plant, except unmarketable fruit yield ( $t / f e d)$ in both seasons of study which did not reach the level of significance during the two seasons of study, compared with the control treatment which gave the lowest values of fruit yield and its components as well as water use efficiency in both seasons. This results are in agreement with those obtained by previouslyFrancesca Boari et al. (2016), Nevenka et al. (2016), Ahmed AbdAllah (2018), Ahmed AbdAllah (2019) and Malash et al. (2019). As for the effect of the interaction treatments between irrigation intervals and foliar spray with some antitranspiration substances, the same data in table (7) revealed that the highest values of the most fruit yield and its components (total yield $\mathrm{kg} / \mathrm{plant}$, total yield $\mathrm{t} /$ fed and marketable yield $\mathrm{t} / \mathrm{fed}$ ) were recorded as a result of using irrigation every 10 days $\left(2850 \mathrm{~m}^{3} / \mathrm{fed}\right)$ followed by irrigation every 15 and 20 days( 2550 and $2150 \mathrm{~m}^{3} / \mathrm{fed}$, respectively) with foliar spray kaolin at concentration $6 \%(60 \mathrm{~g} / \mathrm{L})$ followed by glycine betaine $(2 \mathrm{~g} / \mathrm{L})$ without significant differences among them in both seasons of study. While, irrigation every 10 days and 15 days and spraying with kaolin and glycine betaine recorded the highest values of early yield $\mathrm{kg} /$ plant plus control with no significant differences among them in both seasons. On the other hand, irrigation every 25 days $\left(2100 \mathrm{~m}^{3} / \mathrm{fed}\right)$ recorded the lowest values for all measured fruit yield and its components as well as water use efficiency with all antitranspiration substances especially control treatments in both seasons of study. However, irrigation every 25 days gavethe highest values of unmarketable fruit yield $\mathrm{t} / \mathrm{fed}$ and foliar spray with kaolin and glycine betaine plus control treatment. Moreover irrigated plants after 20 days and 
sprayingkaolin at $6 \%(60 \mathrm{~g} / \mathrm{L})$ recorded the highest values of water use efficiency in both seasons of study.

\section{Physical fruit quality.}

Regarding the effect of irrigation intervals treatments on physical fruit quality of tomato expressed as average fruit weight, length, diameter and fruit firmness, data in table (8) indicated that the most foregoing physical fruit quality traits were significantly increased as a result of using irrigation every 10 and 15 days( irrigation at soil moisture content $\%$ of field capacity) compared with other irrigation treatments under study .Moreover, using irrigation every 10 and 15 days recorded the highest values in all measured physical fruit quality traits without significant differences between them except fruit firmness in both seasons of study. On the other hand. Irrigation every 25 days( irrigation at soil moisture content $\%$ of field capacity) recorded the highest values of fruit firmness and its decreased the fruit weight and fruit length in both seasons. Such improvement in physical fruit traits as a result of using irrigation intervals treatments maybe due to the increase in photosynthetic pigments and mineral elements content (table 6) which affected positively on plant growth(table 5) and consequently on quality of produce fruit. In this concept similar results were reported by Abd El-hady et al. (2017), El-Zawily et al.(2019), Hao Liu et al. (2019),Jia Lu et al. (2019) andJianshe et al. (2019).

With regard to the effect of antitranspiration spray treatments, the same data in Table (12) indicate that spraying tomatoplants with kaolin at concentration of $6 \%(60 \mathrm{~g} / \mathrm{L})$ and glycine betaine $(2 \mathrm{~g} / \mathrm{L})$, three times during the growing season starting after three weeks from transplanting and every two weeks by intervals significantly increased all studied physical fruit quality compared with the control treatment during the two seasons of growth .In this concept, spraying the plants with kaolin exhibited the highest values in all measured growth traits followed by using glycine betaine which recorded the highest values of fruit weight, fruit length, fruit diameter and fruit firmness in both seasons of study compared with the control treatment which gave the lowest values of all physical fruit quality in both seasons. These finding are in agreement with those obtained by previously Francesca Boari et al. (2016), Nevenka et al. (2016), Ahmed Abd-Allah et al. (2018) and Malash et al. (2019).
As for the effect of the interaction treatments between irrigation intervals and foliar spray with some antitranspitation substances, the same data in table (8) revealed that the highest values of all physical fruit quality ( fruit weight, length and diameter ) except fruit firmnesswere recorded as a result of using irrigation every 10 days $\left(2850 \mathrm{~m}^{3} / \mathrm{fed}\right)$ and foliar spray with kaolin $(60 \mathrm{~g} / \mathrm{L})$ followed by glycine betaine $(2 \mathrm{~g} / \mathrm{L})$ act plus control in both seasons of study. While, irrigation every 10 days and 15 days (2850 and $2550 \mathrm{~m}^{3} / \mathrm{fed}$, respectively) recorded the highest values of ( fruit weight, length and diameter ) with spraying by kaolin and glycine betaine plus control with no significant differences among them in both seasons. On the other hand, irrigation every 25 days $\left(2100 \mathrm{~m}^{3} / \mathrm{fed}\right)$ recorded the lowest values for all physical fruit quality except fruit firmnesswith all antitranspiration substances especially control treatments in both seasons of study. Moreover, irrigation every 20 and 25days gave the highest values of fruit firmness with kaolin and glycine betaine in both seasons of study.

\section{Chemical fruit quality:-}

Data presented in table (8) showed the effect of irrigation intervals and antitranspiration substance treatments i.e., kaolin and glycine betaine plus control treatment on chemical fruit quality indices expressed as T.S.S.\% , Vitamin C content and total acidity percentage during the two seasons of study. In this respect, irrigation every 10 days and 15 days ( irrigation at soil moisture content $\%$ of field capacity, respectively)recorded the highest values of vitamin C content in both seasons of study without any significant among them. While, irrigation every 10 , 15 and 20 days recorded the highest values of acidity $\%$ in both seasons compared with otherirrigation treatments under study. On the other hand, irrigation treatments every 25days ( irrigation at soil moisture content $\%$ of field capacity) followed by irrigation every 20 days( irrigation at soil moisture content $\%$ of field capacity) recorded the highest values of T.S.S. without differences significant between them in both seasons of study. However, using irrigation treatment every 25 daysrecorded the lowest values of vitamin C content and acidity in both seasons of study. This results are in agreement with those obtained by previously Abd El-hady et al. (2017), El-Zawily et al.(2019) ,Jia Lu et al. (2019) and Jianshe et al. (2019). 
Table 5. Effect of irrigation intervals, antitranspirants and their interaction on vegetative growth characteristics of tomato plants grown under Kafr-Elsheikh condition during 2017 and 2018 summer seasons .

\begin{tabular}{|c|c|c|c|c|c|c|c|c|c|c|c|c|c|}
\hline \multirow{2}{*}{\multicolumn{2}{|c|}{ Treatments }} & \multirow{2}{*}{\multicolumn{2}{|c|}{$\begin{array}{c}\begin{array}{c}\text { Plant height } \\
(\mathrm{cm})\end{array} \\
\text { Seasons } \\
\end{array}$}} & \multirow{2}{*}{\multicolumn{2}{|c|}{\begin{tabular}{|c|}
$\begin{array}{c}\text { No. of } \\
\text { branches/plant }\end{array}$ \\
Seasons \\
\end{tabular}}} & \multirow{2}{*}{\multicolumn{2}{|c|}{$\begin{array}{c}\text { No. of leaves /plant } \\
\text { Seasons } \\
\end{array}$}} & \multirow{2}{*}{\multicolumn{2}{|c|}{$\begin{array}{c}\begin{array}{c}\text { Fresh weight } \\
\text { (g/plant) }\end{array} \\
\text { Seasons } \\
\end{array}$}} & \multirow{2}{*}{\multicolumn{2}{|c|}{$\begin{array}{c}\begin{array}{c}\text { Dry weight } \\
\text { (g/plant) }\end{array} \\
\text { Seasons } \\
\end{array}$}} & \multirow{2}{*}{\multicolumn{2}{|c|}{$\begin{array}{c}\begin{array}{c}\text { Leaves area } \\
\left(\mathrm{cm}^{2} / \text { plant }\right)\end{array} \\
\text { Seasons } \\
\end{array}$}} \\
\hline & & & & & & & & & & & & & \\
\hline Irrigation intervals & Antitranspirant & 2017 & 2018 & 2017 & 2018 & 2017 & 2018 & 2017 & 2018 & 2017 & 2018 & 2017 & 2018 \\
\hline \multicolumn{2}{|l|}{10 days } & $77.75 \mathrm{a}$ & 79.16 a & $6.87 \mathrm{a}$ & $7.16 \mathrm{a}$ & $61.83 \mathrm{a}$ & $67.41 \mathrm{a}$ & 508.33 a & 523.75 a & $77.75 \mathrm{a}$ & 80.16 a & 4483.33 a & 4527.5 a \\
\hline \multicolumn{2}{|l|}{15 days } & 77.16 a & $73.91 \mathrm{~b}$ & $6.54 \mathrm{a}$ & $6.75 \mathrm{a}$ & $61.58 \mathrm{a}$ & $67.16 \mathrm{a}$ & $\begin{array}{c}504.00 \\
\text { a } \\
\end{array}$ & $521.83 \mathrm{a}$ & 76.58 a & $79.75 \mathrm{a}$ & 4460.41 a & 4513.33 a \\
\hline \multicolumn{2}{|l|}{ 20days } & $70.37 \mathrm{~b}$ & $72.75 \mathrm{~b}$ & $5.91 \mathrm{~b}$ & $6.08 \mathrm{~b}$ & 56.16 b & $57.83 \mathrm{~b}$ & $470.16 \mathrm{~b}$ & $498.33 \mathrm{~b}$ & $76.45 \mathrm{a}$ & $77.83 \mathrm{a}$ & 4354.16 a & 4315 a \\
\hline \multirow[t]{5}{*}{25 days } & & $65.12 \mathrm{c}$ & $62.66 \mathrm{c}$ & $5.83 \mathrm{~b}$ & $6.00 \mathrm{~b}$ & $54.50 \mathrm{~b}$ & $56.41 \mathrm{~b}$ & 332.5 c & $332.08 \mathrm{c}$ & $66.41 \mathrm{~b}$ & $66.16 \mathrm{~b}$ & 3935.83 b & 3975 b \\
\hline & Kaolin & $73.56 \mathrm{a}$ & $72.87 \mathrm{a}$ & $6.56 \mathrm{a}$ & $7.00 \mathrm{a}$ & $60.56 \mathrm{a}$ & $65.18 \mathrm{a}$ & $476.12 \mathrm{a}$ & $492.5 \mathrm{a}$ & $77.96 \mathrm{a}$ & $78.62 \mathrm{a}$ & 4384.37 a & $4431.25 \mathrm{a}$ \\
\hline & Glycine betaine & $72.46 \mathrm{a}$ & 72.06 a & $6.31 \mathrm{~b}$ & $6.40 \mathrm{~b}$ & 57.87 b & $61.56 \mathrm{~b}$ & $446.87 \mathrm{~b}$ & 469.06 b & $73.00 \mathrm{~b}$ & 76.18 b & $4309.37 \mathrm{a}$ & $4301.25 \mathrm{~b}$ \\
\hline & Control & $71.78 \mathrm{a}$ & 71.43 a & $5.90 \mathrm{c}$ & $6.09 \mathrm{c}$ & 57.12 b & 59.87 c & $438.25 \mathrm{~b}$ & $445.43 \mathrm{c}$ & $71.93 \mathrm{~b}$ & $73.12 \mathrm{c}$ & $4231.56 \mathrm{~b}$ & $4265.62 \mathrm{~b}$ \\
\hline & Kaolin & $78.5 \mathrm{a}$ & 80.5 a & $7.25 \mathrm{a}$ & $7.5 \mathrm{a}$ & $64 a$ & $69.5 \mathrm{a}$ & 520 a & 540 a & 80.75 a & 82.5 a & 4525 a & 4575 a \\
\hline \multirow[t]{2}{*}{10 days } & Glycine betaine & $77.75 \mathrm{a}$ & 79 a & $6.75 \mathrm{~b}$ & $7.25 \mathrm{a}$ & $61.25 \mathrm{a}$ & $68 a$ & 510 a & 518.75 a & 77 b & 80.5 a & 4475 a & 4520 a \\
\hline & Control & $77 \mathbf{a}$ & 78 b & $6.62 \mathrm{~b}$ & 6.75 bc & 60.25 bc & $65.75 \mathrm{bc}$ & $495 \mathrm{c}$ & 512.5 bc & 75.5 bc & 77.5 b & 4450 a & 4487.5 a \\
\hline \multirow{3}{*}{15 days } & Kaolin & $78 \mathrm{a}$ & $73.5 \mathrm{~cd}$ & $6.75 \mathrm{~b}$ & $7 \mathbf{a}$ & $64 a$ & 69 a & $515.75 \mathrm{ab}$ & $537.5 \mathrm{a}$ & 80.75 a & 82 a & 4512.5 a & 4550 a \\
\hline & Glycine betaine & 77 a & $72.75 \mathrm{~cd}$ & $6.62 \mathrm{~b}$ & $6.75 \mathrm{bc}$ & 60.25 bc & $67 \mathrm{~b}$ & $502.5 \mathrm{bc}$ & 516.25 bc & 73.75 bc & $79.75 \mathrm{a}$ & 4450 a & 4527.5 a \\
\hline & Control & $76.5 \mathrm{a}$ & $72 \mathrm{~d}$ & 6.25 bc & $6.5 \mathrm{c}$ & 60.5 bc & $64 \mathrm{c}$ & $493.75 \mathrm{c}$ & 511.75 c & 75.25 bc & 77.5 b & 4418.75 a & 4462.5 a \\
\hline \multirow{3}{*}{20 days } & Kaolin & $71 \mathrm{bcd}$ & $74.25 \mathrm{c}$ & $6.37 \mathrm{bc}$ & $6.75 \mathrm{bc}$ & 58 bed & $63.5 \mathrm{bcd}$ & 526.25 a & 540 a & 80.37 a & 82 a & 4500 a & 4550 a \\
\hline & Glycine betaine & $70.25 \mathrm{~cd}$ & $74 \mathrm{~cd}$ & $5.87 \mathrm{~cd}$ & $5.75 \mathrm{~d}$ & 56 cde & 55.25 cde & $443.75 \mathrm{~d}$ & 516.25 bc & 76.25 bc & 80.25 a & $4400 \mathrm{~b}$ & 4220 b \\
\hline & Control & $69.87 \mathrm{~cd}$ & $73.5 \mathrm{~cd}$ & $5.25 \mathrm{e}$ & $5.5 \mathrm{~d}$ & $54.5 \mathrm{de}$ & $54.75 \mathrm{de}$ & $440.5 \mathrm{~d}$ & 438.75 c & $72.75 \mathrm{~cd}$ & $71.25 \mathrm{c}$ & $4162.5 \quad b$ & 4175 b \\
\hline \multirow{3}{*}{25 days } & Kaolin & $66.75 \mathrm{~d}$ & $63.25 \mathrm{e}$ & $6.25 \mathrm{bc}$ & $6.75 \mathrm{bc}$ & $56.25 \mathrm{cde}$ & 58.75 cde & $342.5 \mathrm{e}$ & $352.5 \mathrm{~d}$ & $70 \mathrm{~d}$ & $68 \mathrm{~cd}$ & 4000 bc & 4050 bc \\
\hline & Glycine betaine & $64.87 \mathrm{~d}$ & $62.5 \mathrm{e}$ & $6 \mathrm{c}$ & $5.87 \mathrm{~d}$ & 54 de & $55.5 \mathrm{de}$ & $331.25 \mathrm{e}$ & 325 e & $65 \mathrm{e}$ & $64.25 \mathrm{~d}$ & $3912.5 \mathrm{c}$ & $3937.5 \mathrm{c}$ \\
\hline & Control & $63.75 \mathrm{~d}$ & $62.25 \mathrm{e}$ & $5.5 \mathrm{de}$ & $5.62 \mathrm{~d}$ & 53.25 e & $55 \mathrm{e}$ & $323.75 \mathrm{e}$ & 318.75 e & $64.25 \mathrm{e}$ & $66.25 \mathrm{~d}$ & 3895 c & 3937.5 c \\
\hline
\end{tabular}


Table6. Effect of irrigation intervals, antitranspirant and their interaction on chemical composition of tomato plant foliage grown under Kafr-Elsheikh condition during 2017 and 2018 summer seasons.

\begin{tabular}{|c|c|c|c|c|c|c|c|c|c|c|c|c|c|}
\hline \multirow{2}{*}{\multicolumn{2}{|c|}{ Treatments }} & \multirow{2}{*}{\multicolumn{2}{|c|}{$\begin{array}{c}\text { Chlorophyll reading } \\
\text { Seasons }\end{array}$}} & \multirow{2}{*}{\multicolumn{2}{|c|}{$\begin{array}{c}\begin{array}{c}\text { Proline } \\
\text { (mg/100gd.w) }\end{array} \\
\text { Seasons } \\
\end{array}$}} & \multirow{2}{*}{\multicolumn{2}{|c|}{$\begin{array}{c}\begin{array}{c}\text { Carbohydrates } \\
\text { (g/100gm d.w) }\end{array} \\
\text { Seasons } \\
\end{array}$}} & \multirow{2}{*}{\multicolumn{2}{|c|}{$\begin{array}{c}\mathbf{N} \% \\
\text { Seasons }\end{array}$}} & \multirow{2}{*}{\multicolumn{2}{|c|}{$\begin{array}{c}\text { P \% } \\
\text { Seasons }\end{array}$}} & \multirow{2}{*}{\multicolumn{2}{|c|}{$\begin{array}{c}\mathrm{K} \% \\
\text { Seasons }\end{array}$}} \\
\hline & & & & & & & & & & & & & \\
\hline Irrigation intervals & Antitranspirant & 2017 & 2018 & 2017 & 2018 & 2017 & 2018 & 2017 & 2018 & 2017 & 2018 & 2017 & 2018 \\
\hline 10 days & & 55.41 a & 55.75 a & $7.33 \mathrm{~d}$ & $7.42 \mathrm{~b}$ & $1.65 \mathrm{c}$ & $1.36 \mathrm{c}$ & $3.81 \mathrm{a}$ & $3.85 \mathrm{a}$ & $0.460 \mathrm{a}$ & $0.468 a$ & $3.55 \mathrm{a}$ & $3.59 \mathrm{a}$ \\
\hline 15 days & & 54.5 a & 54.75 a & $7.55 \mathrm{c}$ & $7.61 \mathrm{~b}$ & $1.72 \mathrm{~b}$ & $1.59 \mathrm{~b}$ & $3.77 \mathrm{a}$ & $3.83 \mathrm{a}$ & 0.455 a & $0.465 a$ & $3.53 \mathrm{a}$ & $3.57 \mathrm{a}$ \\
\hline 20days & & $50.08 \mathrm{~b}$ & $50.5 \mathrm{~b}$ & $7.72 \mathrm{~b}$ & $7.75 \mathrm{a}$ & $1.74 \mathrm{~b}$ & $1.75 \mathrm{a}$ & $3.60 \mathrm{~b}$ & $3.72 \mathrm{~b}$ & $0.429 \mathrm{~b}$ & 0.437 b & $3.37 \mathrm{~b}$ & $3.44 \mathrm{~b}$ \\
\hline \multirow[t]{5}{*}{25 days } & & $44.41 \mathrm{c}$ & $45.25 \mathrm{c}$ & $7.8 \mathrm{a}$ & $7.77 \mathrm{a}$ & $1.78 \mathrm{a}$ & $1.77 \mathrm{a}$ & $3.44 \mathrm{c}$ & $3.43 \mathrm{c}$ & $0.358 \mathrm{c}$ & $0.361 \mathrm{c}$ & $3.13 \mathrm{c}$ & $3.15 \mathrm{~b}$ \\
\hline & Kaolin & $52.5 \mathrm{a}$ & 53.06 a & $7.69 \mathrm{a}$ & $7.71 \mathrm{a}$ & $1.71 \mathrm{a}$ & $1.65 \mathrm{a}$ & $3.75 \mathrm{a}$ & $3.77 \mathrm{a}$ & 0.445 a & $0.453 \mathrm{a}$ & $3.48 \mathrm{a}$ & $3.52 \mathrm{a}$ \\
\hline & Glycine betaine & $51.18 \mathrm{~b}$ & $51.5 \mathrm{~b}$ & $7.61 \mathrm{~b}$ & $7.66 \mathrm{a}$ & $1.76 \mathrm{a}$ & $1.61 \mathrm{a}$ & $3.65 \mathrm{~b}$ & $3.7 \mathrm{~b}$ & $0.421 \mathrm{~b}$ & $0.427 \mathrm{~b}$ & $3.4 \mathrm{~b}$ & $3.43 \mathrm{~b}$ \\
\hline & Control & $49.62 \mathrm{c}$ & 50.12 c & $7.5 \mathrm{c}$ & $7.54 \mathrm{~b}$ & $1.67 \mathrm{~b}$ & $1.58 \mathrm{~b}$ & $3.56 \mathrm{c}$ & $3.65 \mathrm{~b}$ & $0.411 \mathrm{~b}$ & $0.418 \mathrm{~b}$ & $3.13 \mathrm{c}$ & $3.35 \mathrm{~b}$ \\
\hline & Kaolin & 56.5 a & 57 a & $7.45 \mathrm{gh}$ & 7.5 cde & 1.72 bc & $1.40 \mathrm{f}$ & 3.95 a & $3.90 \mathrm{a}$ & 0.470 a & 0.480 a & $3.62 \mathrm{a}$ & 3.67 a \\
\hline \multirow{2}{*}{10 days } & Glycine betaine & 55.5 b & 55.75 b & $7.35 \mathrm{~h}$ & 7.42 de & 1.67 cde & $1.36 \mathrm{fg}$ & 3.77 bcd & $3.85 \mathrm{a}$ & 0.460 a & 0.467 a & $3.60 \mathrm{a}$ & $3.62 \mathrm{a}$ \\
\hline & Control & 54.25 c & 54.5 c & $7.2 \mathrm{i}$ & $7.35 \mathrm{e}$ & $1.55 \mathrm{e}$ & $1.32 \mathrm{~g}$ & $3.72 \mathrm{~cd}$ & 3.80 bcd & 0.452 a & 0.457 a & $\begin{array}{l}3.42 \\
\text { bcd }\end{array}$ & $3.48 \mathrm{bc}$ \\
\hline \multirow{3}{*}{15 days } & Kaolin & $57 \mathbf{a}$ & 57.25 a & 7.62 cde & 7.67 bc & 1.75 bcd & $1.65 \mathrm{~d}$ & $3.85 \mathrm{~b}$ & $3.95 \mathrm{a}$ & 0.472 a & 0.482 a & $3.60 \mathrm{a}$ & $3.65 \mathrm{a}$ \\
\hline & Glycine betaine & 54.5 c & 54.75 bc & 7.57 efg & $7.6 \mathrm{c}$ & $1.72 \mathrm{bcd}$ & $1.57 \mathrm{e}$ & $3.80 \mathrm{bc}$ & 3.80 bcd & 0.452 a & 0.462 a & $3.52 \mathrm{~b}$ & $3.57 \mathrm{~b}$ \\
\hline & Control & $52 \mathrm{~d}$ & $52.25 \mathrm{~d}$ & $7.47 \mathrm{fgh}$ & $7.57 \mathrm{~cd}$ & 1.70 bcd & $1.55 \mathrm{e}$ & $3.67 \mathrm{de}$ & $3.76 \mathrm{~cd}$ & 0.440 a & 0.450 a & $3.47 \quad b$ & 3.48 bc \\
\hline \multirow{3}{*}{20 days } & Kaolin & $51.5 \mathrm{~d}$ & $52 \mathrm{~d}$ & $7.82 \mathrm{a}$ & $7.82 \mathrm{a}$ & 1.67 cde & $1.78 \mathrm{a}$ & 3.67 de & $3.75 \mathrm{~cd}$ & 0.452 a & 0.462 a & 3.47 b & $3.55 \mathrm{~b}$ \\
\hline & Glycine betaine & 50 e & 50 e & $7.75 \mathrm{a}$ & $7.8 \mathrm{a}$ & $1.85 \mathrm{a}$ & $1.77 \mathrm{a}$ & 3.60 ef & $3.72 \mathrm{~d}$ & 0.422 a & 0.430 a & $\begin{array}{l}3.35 \\
\text { cde }\end{array}$ & 3.42 bcd \\
\hline & Control & 48.75 e & $49.5 \mathrm{e}$ & 7.6 def & $7.62 \mathrm{c}$ & $1.65 \mathrm{de}$ & $1.72 \mathrm{c}$ & $3.55 \mathrm{f}$ & $3.70 \mathrm{~d}$ & 0.412 a & 0.420 a & 3.30 de & $3.35 \mathrm{~cd}$ \\
\hline \multirow{3}{*}{25 days } & Kaolin & $45 \mathrm{f}$ & $46 \mathrm{f}$ & $7.87 \mathrm{a}$ & $7.85 \mathrm{a}$ & 1.72 bcd & $1.80 \mathrm{a}$ & $3.55 \mathrm{f}$ & $3.5 \mathrm{e}$ & 0.385 a & 0.390 a & 3.22 ef & 3.22 de \\
\hline & Glycine betaine & $44.75 \mathrm{fg}$ & $45.5 \mathrm{fg}$ & $7.8 \mathrm{a}$ & $7.82 \mathrm{a}$ & 1.82 a & $1.77 \mathrm{a}$ & $3.45 \mathrm{~g}$ & 3.42 ef & 0.350 a & 0.350 a & $3.12 \mathrm{fg}$ & 3.12 e \\
\hline & Control & $43.5 \mathrm{~g}$ & $44.25 \mathrm{~g}$ & 7.72 bcd & $7.63 \mathrm{bc}$ & 1.79 bc & $1.73 \mathrm{bc}$ & $3.32 \mathrm{~h}$ & $3.37 \mathrm{f}$ & 0.340 a & 0.340 a & $3.05 \mathrm{~g}$ & $3.10 \mathrm{e}$ \\
\hline
\end{tabular}


Table 7. Effect of irrigation intervals, antitranspirants and their interaction on fruit yield and its components of tomato plants grown under Kafr El-sheikh condition during 2017 and 2018 summer seasons.

\begin{tabular}{|c|c|c|c|c|c|c|c|c|c|c|c|c|c|}
\hline \multirow{3}{*}{$\begin{array}{r}\text { Treatments } \\
\begin{array}{c}\text { Irrigation } \\
\text { intervals }\end{array}\end{array}$} & \multirow{3}{*}{$\begin{array}{l}\text { Characters } \\
\text { Antitranspirant }\end{array}$} & \multirow{2}{*}{\multicolumn{2}{|c|}{$\begin{array}{c}\text { Total yield } \\
\text { (Kg/plant) }\end{array}$}} & \multirow{2}{*}{\multicolumn{2}{|c|}{$\begin{array}{c}\begin{array}{c}\text { Total yield } \\
\text { (t/fed.) }\end{array} \\
\text { seasons } \\
\end{array}$}} & \multirow{2}{*}{\multicolumn{2}{|c|}{$\begin{array}{c}\begin{array}{c}\text { Marketable yield } \\
\text { (t/fed.) }\end{array} \\
\text { Seasons } \\
\end{array}$}} & \multirow{2}{*}{\multicolumn{2}{|c|}{$\begin{array}{c}\begin{array}{c}\text { Unmarketable } \\
\text { yield } \\
\text { (t/fed.) }\end{array} \\
\text { seasons } \\
\end{array}$}} & \multirow{2}{*}{\multicolumn{2}{|c|}{$\begin{array}{c}\begin{array}{c}\text { Early yield } \\
\text { (Kg/plant) }\end{array} \\
\text { Seasons } \\
\end{array}$}} & \multirow{2}{*}{\multicolumn{2}{|c|}{$\begin{array}{c}\begin{array}{c}\text { WUE } \\
\left(\mathrm{Kg} / \mathbf{m}^{3}\right)\end{array} \\
\text { seasons } \\
\end{array}$}} \\
\hline & & & & & & & & & & & & & \\
\hline & & 2017 & 2018 & 2017 & 2018 & 2017 & 2018 & 2017 & 2018 & 2017 & 2018 & 2017 & 2018 \\
\hline 10 days & & $4.64 \mathrm{a}$ & $4.71 \mathrm{a}$ & $31.25 a$ & $31.68 \mathrm{a}$ & $29.24 \mathrm{a}$ & 29.70 a & $2.01 \mathrm{~b}$ & $1.98 \mathrm{c}$ & $2.05 \mathrm{a}$ & 2.07 a & $11.57 \mathrm{c}$ & $11.58 \mathrm{c}$ \\
\hline 15 days & & $4.60 \mathrm{a}$ & $4.70 \mathrm{a}$ & $31.00 \mathrm{a}$ & $31.65 \mathrm{a}$ & 28.89 a & $29.52 \mathrm{a}$ & $2.09 \mathrm{~b}$ & $2.13 \mathrm{~b}$ & $1.95 \mathrm{~b}$ & $1.99 \mathrm{~b}$ & $12.39 \mathrm{~b}$ & $12.41 \mathrm{~b}$ \\
\hline 20days & & $4.55 \mathrm{a}$ & $4.66 \mathrm{a}$ & 30.87 a & $31.64 \mathrm{a}$ & 28.72 a & $29.50 \mathrm{a}$ & $2.15 \mathrm{~b}$ & $2.13 \mathrm{~b}$ & $1.45 \mathrm{c}$ & $1.47 \mathrm{c}$ & $13.13 \mathrm{a}$ & 13.18 a \\
\hline \multirow[t]{5}{*}{25 days } & & $3.89 \mathrm{~b}$ & $4.05 \mathrm{~b}$ & 26.03 b & $27.27 \mathrm{~b}$ & $23.41 \mathrm{~b}$ & 24.69 b & $2.45 \mathrm{a}$ & 2.49 a & $1.01 \mathrm{~d}$ & $0.94 \mathrm{~d}$ & $11.49 \mathrm{c}$ & $11.63 \mathrm{c}$ \\
\hline & Kaolin & $4.57 \mathrm{a}$ & $4.62 \mathrm{a}$ & 30.89 a & $31.11 \mathrm{a}$ & 28.77 a & $29.27 \mathrm{a}$ & $2.12 \mathrm{a}$ & $2.11 \mathrm{a}$ & $1.70 \mathrm{a}$ & $1.69 \mathrm{a}$ & $12.63 \mathrm{a}$ & $12.39 \mathrm{a}$ \\
\hline & Glycine betaine & $4.42 \mathrm{~b}$ & $4.55 \mathrm{~b}$ & 29.77 b & $30.62 \mathrm{~b}$ & $27.59 \mathrm{~b}$ & $28.37 \mathrm{~b}$ & $2.17 \mathrm{a}$ & $2.20 \mathrm{a}$ & $1.59 \mathrm{~b}$ & $1.59 \mathrm{~b}$ & $12.15 \mathrm{~b}$ & $12.20 \mathrm{~b}$ \\
\hline & Control & $4.27 \mathrm{c}$ & $4.41 \mathrm{c}$ & 28.69 c & 29.95 c & $26.34 \mathrm{c}$ & $27.42 \mathrm{c}$ & $2.23 \mathrm{a}$ & $2.23 \mathrm{a}$ & $1.55 \mathrm{~b}$ & $1.57 \mathrm{~b}$ & $11.66 \mathrm{c}$ & $11.95 \mathrm{c}$ \\
\hline & Kaolin & $4.75 \mathrm{a}$ & $4.78 \mathrm{a}$ & 31.95 a & 32.19 a & 29.97 a & $30.29 \mathrm{a}$ & $1.97 \mathrm{~d}$ & $1.9 \mathrm{c}$ & 2.07 a & $2.10 \mathrm{a}$ & $11.82 \mathrm{de}$ & $11.7 \mathrm{fg}$ \\
\hline \multirow{2}{*}{10 days } & Glycine betaine & $4.67 \mathrm{ab}$ & $4.7 \mathrm{a}$ & $31.42 \mathrm{ab}$ & $\begin{array}{c}31.61 \\
\text { ab }\end{array}$ & 29.34 b & $29.61 \mathrm{bc}$ & 2.07 bcd & $2 \mathrm{c}$ & 2.05 a & 2.06 a & 11.63 efg & $11.49 \mathrm{gh}$ \\
\hline & Control & $4.52 \mathrm{bcd}$ & $4.64 \mathrm{bcd}$ & 30.4 bc & $31.23 \mathrm{c}$ & $\begin{array}{c}28.40 \\
\text { cde }\end{array}$ & 29.19 c & $1.99 \mathrm{~cd}$ & 2.04 bc & 2.03 a & $2.05 \mathrm{a}$ & $11.25 \mathrm{~g}$ & $11.35 \mathrm{~h}$ \\
\hline \multirow{3}{*}{15 days } & Kaolin & $4.75 \mathrm{a}$ & $4.79 \mathrm{a}$ & 31.93 a & 32.20 a & 29.82 a & 30.08 a & 2.11 bcd & 2.12 bc & $2.02 \mathrm{a}$ & $2.11 \mathrm{a}$ & 12.76 bc & $12.62 \mathrm{c}$ \\
\hline & Glycine betaine & $4.61 \mathrm{bc}$ & $4.71 \mathrm{a}$ & $31.02 \mathrm{ab}$ & $\begin{array}{c}31.70 \\
\text { ab }\end{array}$ & $28.87 \mathrm{bcd}$ & 29.58 bc & $2.14 \mathrm{bcd}$ & $2.12 \mathrm{bc}$ & 1.92 a & $1.95 \mathrm{a}$ & $12.40 \mathrm{~cd}$ & $12.43 \mathrm{~cd}$ \\
\hline & Control & $4.46 \mathrm{~cd}$ & $4.61 \mathrm{~cd}$ & $30.04 \mathrm{c}$ & $31.06 \mathrm{c}$ & 28 de & 28.91 c & 2.04 bcd & $2.14 \mathrm{bc}$ & $1.9 \mathrm{a}$ & $1.92 \mathrm{a}$ & $12.01 \mathrm{de}$ & $12.17 \mathrm{de}$ \\
\hline \multirow{3}{*}{20 days } & Kaolin & $4.7 \mathrm{a}$ & $4.76 \mathrm{a}$ & $31.77 \mathrm{a}$ & $32.1 \mathrm{a}$ & 29.75 a & $30.02 \mathrm{a}$ & $2.02 \mathrm{~cd}$ & 2.07 bc & $1.52 \mathrm{c}$ & $1.55 \mathrm{c}$ & $13.51 \mathrm{a}$ & 13.37 a \\
\hline & Glycine betaine & 4.57 bcd & $4.7 \mathrm{a}$ & 30.9 ab & $31.5 \mathrm{ab}$ & 28.82 bcd & 29.37 bc & 2.08 bcd & 2.12 bc & $1.43 \mathrm{c}$ & $1.46 \mathrm{c}$ & $13.14 \mathrm{~b}$ & $13.12 \mathrm{~b}$ \\
\hline & Control & $4.4 \mathrm{~d}$ & $4.52 \mathrm{~d}$ & 29.94 c & $\begin{array}{c}31.32 \\
\text { bc }\end{array}$ & 27.59 e & 29.12 c & $2.35 \mathrm{ab}$ & $2.20 \mathrm{bc}$ & $1.4 \mathrm{c}$ & $1.42 \mathrm{c}$ & $12.74 \mathrm{bc}$ & $13.04 \mathrm{~b}$ \\
\hline \multirow{3}{*}{25 days } & Kaolin & $4.10 \mathrm{e}$ & $4.15 \mathrm{e}$ & $27.93 \mathrm{~d}$ & $27.95 \mathrm{~d}$ & $25.55 \mathrm{f}$ & $26.71 \mathrm{~d}$ & 2.38 a & $2.37 \mathrm{a}$ & $1.17 \mathrm{~d}$ & $1.02 \mathrm{~d}$ & $12.41 \mathrm{~cd}$ & 11.89 ef \\
\hline & Glycine betaine & $3.85 \mathrm{f}$ & $4.11 \mathrm{e}$ & 25.75 e & $27.66 \mathrm{~d}$ & $23.33 \mathrm{~g}$ & 24.92 e & $2.42 \mathrm{a}$ & $2.57 \mathrm{a}$ & 0.975 e & 0.92 e & $11.44 \mathrm{fg}$ & $11.76 \mathrm{fg}$ \\
\hline & Control & $370 \mathrm{f}$ & $3.88 \mathrm{f}$ & $24.38 \mathrm{f}$ & 26.19 e & $21.36 \mathrm{~h}$ & $22.45 \mathrm{f}$ & $2.55 \mathrm{a}$ & $2.53 \mathrm{a}$ & 0.885 e & 0.90 e & $10.63 \mathrm{~h}$ & $11.25 \mathrm{~h}$ \\
\hline
\end{tabular}


Table 8. Effect of irrigation intervals, antitranspirant and their interaction on physical and chemical fruit quality of tomato plants grown under Kfr-Elsheikh condition during 2017 and 2018 summer seasons.

\begin{tabular}{|c|c|c|c|c|c|c|c|c|c|c|c|c|c|c|c|}
\hline \multirow{3}{*}{$\begin{array}{c}\text { Treatments } \\
\begin{array}{l}\text { Irrigation } \\
\text { intervals }\end{array} \\
\end{array}$} & \multirow{3}{*}{$\begin{array}{c}\text { Characters } \\
\text { ntitranspirant }\end{array}$} & \multirow{2}{*}{\multicolumn{2}{|c|}{$\begin{array}{c}\text { Fruit weight }(\mathrm{g}) \\
\text { Seasons }\end{array}$}} & \multirow{2}{*}{\multicolumn{2}{|c|}{$\begin{array}{c}\text { Fruit length }(\mathbf{c m}) \\
\text { Seasons }\end{array}$}} & \multirow{2}{*}{\multicolumn{2}{|c|}{$\begin{array}{c}\begin{array}{c}\text { Fruit diameter } \\
(\mathrm{cm})\end{array} \\
\text { Seasons } \\
\end{array}$}} & \multirow{2}{*}{\multicolumn{2}{|c|}{$\begin{array}{c}\begin{array}{c}\text { Fruit firmness } \\
\left(\mathrm{g} / \mathrm{cm}^{2}\right)\end{array} \\
\text { Seasons } \\
\end{array}$}} & \multirow{2}{*}{\multicolumn{2}{|c|}{$\begin{array}{l}\text { T.S.S \% } \\
\text { Seasons } \\
\end{array}$}} & \multirow{2}{*}{\multicolumn{2}{|c|}{$\begin{array}{c}\text { V.C }(\mathrm{mg} / \mathbf{1 0 0 g}) \\
\text { Seasons } \\
\end{array}$}} & \multirow{2}{*}{\multicolumn{2}{|c|}{$\begin{array}{c}\text { Acidity } \% \\
\text { Seasons } \\
\end{array}$}} \\
\hline & & & & & & & & & & & & & & & \\
\hline & & 2017 & 2018 & 2017 & 2018 & 2017 & 2018 & 2017 & 2018 & 2017 & 2018 & 2017 & 2018 & 2017 & 20181 \\
\hline 10 days & & 13027 a & 130.83 a & $5.54 \mathrm{a}$ & $5.56 \mathrm{a}$ & $5.8 \mathrm{a}$ & $5.85 \mathrm{a}$ & $431.25 \mathrm{~b}$ & $432 \mathrm{~b}$ & $4.55 \mathrm{c}$ & $4.85 \mathrm{~b}$ & $3.57 \mathrm{a}$ & $3.6 \mathrm{a}$ & $1.58 \mathrm{a}$ & $1.64 \mathrm{a}$ \\
\hline 15 days & & 122.27 a & $122.11 \mathrm{a}$ & $5.40 \mathrm{a}$ & $5.44 \mathrm{a}$ & $5.16 \mathrm{~b}$ & $5.22 \mathrm{~b}$ & 431.66 b & $433.33 \mathrm{~b}$ & $4.77 \mathrm{~b}$ & $4.69 \mathrm{~b}$ & $3.35 \mathrm{a}$ & $3.51 \mathrm{a}$ & $1.49 \mathrm{a}$ & $1.5 \mathrm{a}$ \\
\hline 20days & & 111.38 b & $112.81 \mathrm{~b}$ & $5.17 \mathrm{~b}$ & $5.24 \mathrm{~b}$ & $5.18 \mathrm{~b}$ & $5.4 \mathrm{~b}$ & 453.33 a & 462.08 a & $5.29 \mathrm{a}$ & $5.3 \mathrm{a}$ & $3.18 \mathrm{~b}$ & $3.11 \mathrm{~b}$ & $1.44 \mathrm{a}$ & $1.48 \mathrm{a}$ \\
\hline \multirow[t]{4}{*}{25 days } & & $108.61 \mathrm{~b}$ & 109.44 b & $5.16 \mathrm{~b}$ & $5.22 \mathrm{~b}$ & $5.33 \mathrm{~b}$ & $5.40 \mathrm{~b}$ & 459.58 a & $462.91 \mathrm{a}$ & $5.43 \mathrm{a}$ & $5.5 \mathrm{a}$ & $2.7 \mathrm{c}$ & $2.88 \mathrm{c}$ & $1.21 \mathrm{~b}$ & $1.23 \mathrm{~b}$ \\
\hline & Kaolin & 122.91 a & 124.68 a & $5.4 \mathrm{a}$ & $5.42 \mathrm{a}$ & $5.45 \mathrm{a}$ & $5.52 \mathrm{a}$ & $451.25 \mathrm{a}$ & $456.56 \mathrm{a}$ & $5.08 \mathrm{a}$ & $5.16 \mathrm{a}$ & $3.3 \mathrm{a}$ & $3.34 \mathrm{a}$ & $1.54 \mathrm{a}$ & $1.58 \mathrm{a}$ \\
\hline & Glycine betaine & $119.37 \mathrm{a}$ & $120.00 \mathrm{~b}$ & $5.31 \mathrm{~b}$ & $5.36 \mathrm{~b}$ & $5.36 \mathrm{~b}$ & $5.46 \mathrm{~b}$ & $445 \mathrm{~b}$ & $448.43 \mathrm{~b}$ & 5.03 a & 5.10 a & $3.19 \mathrm{~b}$ & $3.27 \mathrm{a}$ & $1.44 \mathrm{a}$ & $1.47 \mathrm{a}$ \\
\hline & Control & $110.62 \quad b$ & $111.87 \mathrm{c}$ & $5.25 \mathrm{c}$ & $5.31 \mathrm{~b}$ & $5.3 \mathrm{c}$ & $5.41 \mathrm{~b}$ & $435.62 \mathrm{c}$ & $438.12 \mathrm{c}$ & $4.92 \mathrm{~b}$ & $5.03 \mathrm{a}$ & $3.11 \mathrm{c}$ & $3.21 \mathrm{a}$ & $1.31 \mathrm{~b}$ & $1.33 \mathrm{~b}$ \\
\hline \multirow[t]{3}{*}{10 days } & Kaolin & 133.33 a & 134.16 a & $5.57 \mathrm{a}$ & $5.57 \mathrm{a}$ & $5.85 \mathrm{a}$ & $5.9 \mathrm{a}$ & $438.7 \mathrm{~cd}$ & 440 cd & $4.6 \mathrm{de}$ & $4.9 \mathrm{~d}$ & $3.62 \mathrm{a}$ & $3.65 \mathrm{a}$ & $1.7 \mathrm{a}$ & $1.75 \mathrm{a}$ \\
\hline & Glycine betaine & 131.66 a & 130.83 a & $5.57 \mathrm{a}$ & $5.6 \mathrm{a}$ & 5.8 a & 5.85 a & 430 ef & 432.5 ef & $4.55 \mathrm{de}$ & $4.85 \mathrm{de}$ & $3.57 \mathrm{a}$ & $3.6 \mathrm{a}$ & $1.6 \mathrm{a}$ & $1.62 \mathrm{a}$ \\
\hline & Control & $125.83 \mathrm{~b}$ & 127.5 a & $5.47 \mathrm{a}$ & $5.52 \mathrm{a}$ & $5.75 \mathrm{a}$ & 5.8 a & $425 \mathrm{fg}$ & $425 \mathrm{fg}$ & $4.5 \mathrm{e}$ & 4.8 def & $3.52 \mathrm{a}$ & $3.55 \mathrm{a}$ & $1.45 \mathrm{bcd}$ & $1.55 \mathrm{a}$ \\
\hline \multirow{3}{*}{15 days } & Kaolin & 130.83 a & 133.33 a & $5.5 \mathrm{a}$ & 5.52 a & $5.4 \mathrm{~b}$ & 5.42 bc & $442.5 \mathrm{c}$ & $445 \mathrm{c}$ & $4.85 \mathrm{c}$ & 4.75 def & 3.4 bc & $3.55 \mathrm{a}$ & $1.7 \mathrm{a}$ & $1.52 \mathrm{a}$ \\
\hline & Glycine betaine & $123.33 \mathrm{bc}$ & $125.83 \mathrm{~b}$ & 5.37 bc & 5.42 bc & 5.32 bc & 5.4 bcd & 432.5 de & 435 de & $4.77 \mathrm{~cd}$ & 4.7 ef & $3.35 \mathrm{~cd}$ & $3.5 \mathrm{a}$ & $1.55 \mathrm{a}$ & $1.5 \mathrm{a}$ \\
\hline & Control & $106.66 \mathrm{~d}$ & $107.5 \mathrm{~d}$ & $5.35 \mathrm{~cd}$ & $5.37 \mathrm{~cd}$ & $5.27 \mathrm{~cd}$ & 5.37 bcd & $420 \mathrm{~g}$ & $420 \mathrm{~g}$ & 4.7 cde & $4.62 \mathrm{f}$ & $3.3 \mathrm{~d}$ & $3.5 \mathrm{a}$ & $1.22 \mathrm{de}$ & $1.47 \mathrm{bcd}$ \\
\hline \multirow[t]{3}{*}{20 days } & Kaolin & $\begin{array}{c}116.66 \\
\text { bed }\end{array}$ & $\begin{array}{c}117.91 \\
\text { bc }\end{array}$ & 5.27 cde & $5.3 \mathrm{de}$ & $5.3 \mathrm{bc}$ & $5.47 \mathrm{~b}$ & $460 \mathrm{a}$ & $470 \mathrm{a}$ & $5.4 \mathrm{a}$ & $5.45 \mathrm{a}$ & 3.25 de & $3.2 \mathrm{bc}$ & $1.5 \mathrm{a}$ & $1.75 \mathrm{a}$ \\
\hline & Glycine betaine & $\begin{array}{c}114.16 \\
\text { bed }\end{array}$ & $\begin{array}{c}115.00 \\
\text { cd }\end{array}$ & 5.17 efg & 5.2 ef & 5.17 def & 5.4 bcd & $457.5 \mathrm{a}$ & 466.25 a & $5.3 \mathrm{a}$ & 5.37 bc & 3.22 de & $3.12 \mathrm{~cd}$ & $1.4 \mathrm{bcd}$ & $1.55 \mathrm{a}$ \\
\hline & Control & $103.33 \mathrm{~d}$ & $105.88 \mathrm{~d}$ & $5.07 \mathrm{~g}$ & 5.22 ef & $5.07 \mathrm{f}$ & $5.35 \mathrm{~cd}$ & $442.5 \mathrm{c}$ & $450 \mathrm{~b}$ & 5.18 b & $5.27 \mathrm{c}$ & 3.07 ef & $3.02 \mathrm{~d}$ & 1.4 bed & $1.15 \mathrm{e}$ \\
\hline \multirow[t]{3}{*}{25 days } & Kaolin & $110.83 \mathrm{~cd}$ & $\begin{array}{c}113.33 \\
\text { cd }\end{array}$ & 5.25 def & 5.3 de & 5.25 cde & 5.3 de & $463.7 \mathrm{a}$ & 471.25 a & $5.5 \mathrm{a}$ & 5.57 a & $2.92 \mathrm{f}$ & $2.97 \mathrm{~d}$ & 1.27 cde & 1.3 bcde \\
\hline & Glycine betaine & $108.33 \mathrm{~d}$ & $108.33 \mathrm{~d}$ & $5.15 \mathrm{fg}$ & 5.22 ef & 5.15 ef & 5.22 ef & $460 \mathrm{a}$ & $460 a$ & $5.5 \mathrm{a}$ & $5.5 \mathrm{a}$ & $2.62 \mathrm{~g}$ & $2.87 \mathrm{~d}$ & $1.22 \mathrm{de}$ & 1.22 cde \\
\hline & Control & $106.66 \mathrm{~d}$ & $106.33 \mathrm{~d}$ & $5.1 \mathrm{~g}$ & $5.15 \mathrm{f}$ & $5.1 \mathrm{f}$ & $5.15 \mathrm{f}$ & $455 \mathrm{~b}$ & $457.5 \mathrm{~b}$ & $5.3 \mathrm{a}$ & $5.42 \mathrm{a}$ & $2.57 \mathrm{~g}$ & $2.8 \mathrm{~d}$ & $1.15 \mathrm{e}$ & $1.17 \mathrm{de}$ \\
\hline
\end{tabular}


With regard to the effect of foliar spray with some antitranspiration substances, the same data in Table (8) indicate that spraying tomato plants with kaolin at concentration of $6 \%(60 \mathrm{~g} / \mathrm{L})$ and glycine betaine $(2 \mathrm{~g} / \mathrm{L})$, three times during the growing season starting after three weeks from transplanting and every two weeks by intervals significantly increased all studied chemical fruit quality compared with the control treatment during the two seasons of growth .In this concept, spraying the plants with kaolin exhibited the highest values in all measured chemical fruit quality (V.C, T.S.S.\% and acidity \%) followed by using glycine betaine with no significant differences between them compared with the control treatment in both seasons of study. These finding are in agreement with those obtained by previously Francesca Boari et al. (2016), Nevenka et al. (2016), Ahmed AbdAllah et al. (2018) and Malash et al. (2019).

As for the effect of the interaction between irrigation intervals and foliar spray with some antitranspitation substances, the same data in table (8) revealed that the highest values of the most chemical fruit quality (V.Cand acidity \%except T.S.S.\%)were recorded as a result of using irrigation treatment every 10 days with kaolin followed by glycine betaine plus control in both seasons of study . Moreover, the irrigation every 10 days and 15 days (2850 and $2550 \mathrm{~m}^{3} / \mathrm{fed}$, respectively) recorded the highest values of (V.C and acidity \% ) and spraying with kaolin and glycine betaine plus control with no significant differences among them in both seasons. On the other hand, irrigation every 25 days $(2100$ $\mathrm{m}^{3} /$ fed) recorded the lowest values for(V.C and acidity )with foliar spraying by all antitranspiration substances especially control treatments in both seasons of study. However, irrigation every 20 and 25 days(2150 and $2100 \mathrm{~m}^{3} / \mathrm{fed}$, respectively) gave the highest values of T.S.S \% while foliar sprayedwith kaolin and glycine betaine in both seasons of study

\section{References}

A.O.A.C. 1990. Official methods of analysis. Association of official analytical chemists. $15^{\text {th }} \mathrm{ed}$. Washington D.C., USA.

Abdalaali, H.H., C.H. Abdul-Jabar and A.M. Abdulkareem (2012). Effect of mulching , irrigation regime and $\mathrm{N}$ fertilization on dry weight and N-uptake of tomato plant.

Abdelhady S.A., N.A.I. Abu El-Azm and S.H. ElKafafi (2017). Effect of deficit irrigation levels and NPK fertilization rates on tomato growth, yield and fruits quality. J. Agric. Res. (03):587604.

Aghaie P., S.A.H. Tafreshi, M.A. Ebrahimi and M. Haerinasab (2018). Tolerance evaluation and clustering of fourteen tomato cultivars grown under mild and severe drought conditions. J. Sci. Hort. $232: 1-12$.
Bates, L.S., R.P. Waldern and I.D. Teare1973. Rapid determination of free proline water stress studies. Plant and Soil,39: 205-207.

Black, C.A., D.O. Evans, LE. Ensminger, J.L. White, F.E. Clark and R.C. Dinauer (1982). Methods of soil analysis. part 2. Chemical and microbiological properties. 2nd ed. Soil Sci., Soc. of Am. Inc. Publ., Madison, Wisconsin, U. S.A.

Brown, J. and O. Lilleland (1946). Rapid determination of potassium and sodium in plant material and soil extracts by flame photometric. Proc. Amer. Soc. Hort. Sci., 48: 341- 346.

Cherry, J.H. (1973): Molecular biology of plants test-Manual. Clombia Univ. Press. New York and London 68-71.

Cruz, C. E., Martínez, M. A. J., Moriana, A., Girón, I. F., Palomo, M. J. M., Galindo, A., Lópezg, P. D., Torrecillas, A., Sinchiguano, B. E. and Corell, M., 2019. Yield response to regulated deficit irrigation of greenhouse cherry tomatoes. J. Agric., Water Management (213): 212-221.

El-Zawily A. S., M. Meleha, M. El-Sawya, H. ElAttarb, Y. Bayoumia, T. Alshaal (2019). Application of magnetic field improves growth, yield and fruit quality of tomato irrigated alternatively by fresh and agricultural drainage water. Ecotoxicology and Environmental Safety (181): 248-254.

Jackson, M.L. (1973). Soil Chemical Analysis. Printice-Hall of India. Privat Limited, New Delhi.

Jianshe L., Y. Gaoa, X. Zhanga, P. Tiana, J. Lia and Y. Tiana (2019). Comprehensive comparison of different saline water irrigation strategies for tomato production: Soil properties, plant growth, fruit yield and fruit quality. Agric. Water Management, 213 : 521-533

John, M.K. (1970). Colorimetric determination of phosphorus in soil and plant material with ascorbic acid. Soil Sci., 109: 214-220.

Kirda, C. 2002. Deficit irrigation scheduling based on plant growth stages showing water stress tolerance. Deficit irrigation practices. In: FAO Corp. Doc. Rep. 22, Rome, 3-10.

Lgbadun, H.E., B.A. Salim, A.K.P.R. Tarimo and H.F. Mahoo. 2008. Effect of deficit irrigation Scheduling on yields and soil water balance of irrigated maize. Irrigation Sci., 27: 11-23.

Liu, H., Li, H., Ning, H., Zhang, X., Li, S., Pang, J., Wang, G. and Sun, J., 2019. Optimizing irrigation frequency and amount to balance yield, fruit quality and water use efficiency of greenhouse tomato. J. Agric., Water Management, (226) :105787.

Lu, J., Shao, G., Cui, J., Wang, X. and Keabetswe, L.(2019). Yield, fruit quality and water use efficiency of tomato for processing under regulated deficit irrigation: A meta-analysis. J. Agric., Water Management (222): 301-312. 
Luvai A.K., A.N. Gitau, B.N.K. Njoroge and J.P.O. Obiero 2014. Effect of water application levels on growth characteristics and soil water balance of tomatoes in green house. International Journal of Engineering Innovation, Res. 3: 271- 278.

Malash , N.M., M.A. Fattahalla, M.R. Khalil and E.S.A. Ibrahim 2019. Enhancing drought tolerance of tomato plants grown under different irrigation regimes by some cultural practices. Menoufia J. Plant prod., 4 (6) :181-205.

Murquard, R. D. and J. L. Timpton (1987). Relationship between extractable chlorophyll and an in-situ method to estimate leaf green. Hort. Sci., 22(6): 1327.

Oweis, T. and A. Hachum. 2001. Reducing peak supplemental irrigation demand by extending sowing dates. Agric. Water Management, 50:109 -124 .

Pazzaglia T. P., J. Weinerb and F. Liua (2016). Effects of CO2elevation and irrigation regimes on leaf gas exchange, plant water relations, and water use efficiency of two tomato cultivars. Agric. Water Management.,(169) : 26-33.

Pereira, L.S., T. Oweis and A. Zairi. 2002. Irrigation management under water scarcity. Agric. Water Management, 57: 175-206.

Pregl, E. (1945). Quantitative organic micro analysis. $4^{\text {th }}$ ed. J. Chundril, London.

Rahil M., H. Hajjeh and A. Qanadillo.(2013). Effect of Saline Water Application through
Different Irrigation Intervals on Tomato Yield and Soil Properties. J. Soil Science, 3: 143-147.

Topcu, S., Kidra, C., Dasgan, Y., Kaman, H., Cetin, M., Yazici, A. and M. A. Bacon. 2007. Yield response and $\mathrm{N}$-fertilizer recovery of tomato grown under deficit irrigation. Eur. J. of Agro., 26: 64-70.

Valcárcel, M., Lahoz, I., Campillo, C., Martí R., Brondo, L. M., Rosello, S. and Cornejo, C. J., 2019 Controlled deficit irrigation as a watersaving strategy for processing tomato. J. Sci. Horti., .

Whab-Allah, M.A. and A.M. Al-Omran(2012). Effect of water quality and deficit irrigation on tomato growth, yield and water use efficiency at different developmental stages. J. Agric. Env. Dam. Univ., Egypt., 11(2): 80-110.

Zhou, H., Shaozhong, K., Fusheng L., Taisheng, D., Manoj K. S. and Xiaojie, L., 2020. Nitrogen application modified the effect of deficit irrigation on tomato transpiration, and water use efficiency in different growth stages. J. Sci. Hort., (263): 109112.

Zhu, J., L. Yinli, Y. Zhu, W. Hao, X. Lin, X. Wu and A. Luo (2012). The interactive effects of water and fertilizer on photosynthetic capacity and yield in tomato plants. AJCS, 6(2):200-209. 